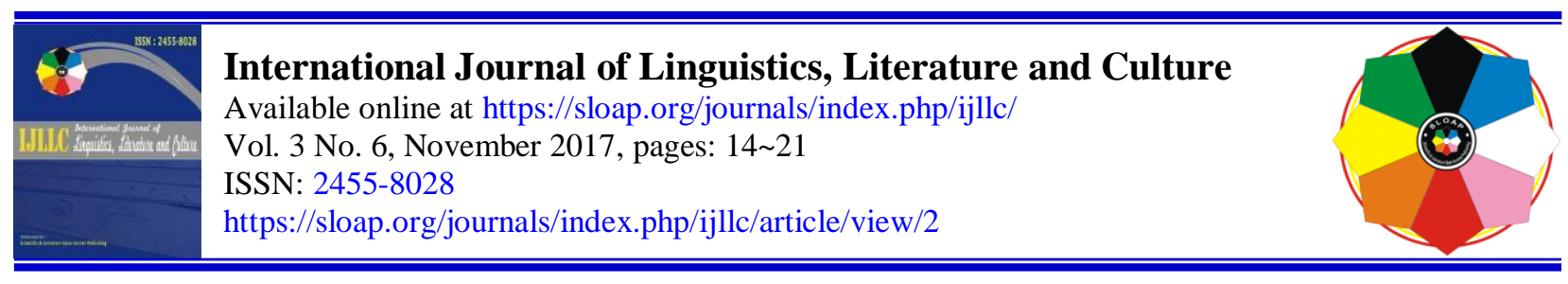

\title{
Identification of Anggah-Ungguh Kruna Balinese Language
}

I Nyoman Suwija ${ }^{a}$

\section{Article history:}

Received: 7 May 2017

Revised: 10 October 2017

Approved: 28 October 2017

Published: 2 November 2017

\section{Keywords:}

Anggah-Ungguh Kruna; Identification of Balinese Word Level;

\begin{abstract}
Balinese language is one of the regional languages in Indonesia that has a unique talk system, it is still alive and used as an instrument of communication of Balinese tribe so that it should be well maintained in order to still exist as a cultural vehicle of Bali. The Balinese language has anggahungguh kruna (level-word) that an important role in the formation of speechlevel or anggah-ungguh basa Bali. This paper aims to describe the identification anggah-ungguh kruna (word level arrangement) which is the specific feature of speaking Balinese. This research is a qualitative research discuss with structuralism theory. Data collection was done by observation and interview method, assisted by recording technique. The collected data is processed by analytical descriptive method. Based on the results of data analysis, it can be described that anggah-ungguh kruna basa Bali include: (1) kruna nenten alus (kruna kasar, mider, and andap); (2) kruna alus, include: (kruna alus singgih, alus sor, alus mider, and alus madia).
\end{abstract}

2455-8028 ${ }^{\circledR}$ Copyright 2017. The Author. This is an open-access article under the CC BY-SA license (https://creativecommons.org/licenses/by-sa/4.0/) All rights reserved.

\section{Author correspondence: \\ I Nyoman Suwija, \\ Indonesian and Regional Education Studies Program Faculty of Language and Arts Education, \\ IKIP PGRI Bali-Indonesia \\ Email address : inyoman.suwija63@gmail.com}

\section{Introduction}

Suarjana (2011: 1-2) says that language has a very important role in the life of mankind, in addition as the identity of a nation also with language can express an ethnicity of a particular group. Similarly, Balinese language it is able to become the identity and identity of Balinese people.

Balinese language is not only a reflection of a community, but also as a reflection of all aspects of Balinese ethnic life. In addition, the Balinese language is also a local language as well as the language of instruction in the association that plays as the mother language of the tribe of Bali, as well as the language of introduction in the association in the household and in all aspects of Balinese life.

The Balinese language is one of the great regional languages in Indonesia because it is still well-lived, maintained and used as an communication tool in Balinese tribe. As a communication tool, Balinese language can be distinguished on the basa pakraman and basa pasuitrayan. Basa pakraman is the language that used by a means of communication in customary and religious official forums such as in paruman or meetings, village meetings, youth meetings, subak meetings, pakeling (announcement) or sembrama wecana (greeting) at

a Indonesian and Regional Education Studies Program Faculty of Language and Arts Education, IKIP PGRI Bali-Indonesia 
traditional ceremonies and religion, as well as official forums such as the language of Balinese language teachers who teach in the classroom. While the term basa pasuitrayan is a language of communication outside the official regional forums such as peer-to-peer farmers, fellow students in the canteen, fellow employees in the office, between buyers and traders in traditional markets, and so forth.

Related to the condition of Bali area is as tourist area and tourism of Bali is cultural tourism, hence strategic role of Balinese language is very clear as Balinese vehicle cultural. Therefore, the Balinese language must be well preserved in order to remain sustainable. Balinese language defense can be done through formal education, as well as in various activities of Balinese people who have customary organizations such as desa adat, banjar adat, seka subak, saka santi, seka teruna, seka gong, seka arja, and so on. All of these customary organizations use Balinese language media on each activity.

Therefore, the importance of the role and function of the regional language of Bali, the Regional Government of Bali Province has issued the Bali Regional Regulation no. 3 of 1992 on Balinese Language, Literature and Literature Development. Based on the regulation, the Head of Regional Office of Bali Province Education Department issued Decree No.22/I.19C/ Kep/I./1994. The Decree stipulates that the local language of Bali should be included as a compulsory local content subject from elementary to high school / vocational school level.

After the enactment of the 2013 Curriculum, the Regional Government of Bali also issued the Bali Governor's Regulation no. 20 of 2013 on Balinese Language, Script and Literature, which in principle requires Balinese language subjects at primary and secondary education, at least 2 hours per week. It was also affirmed that the regent or mayor may appoint Balinese language teachers.

With regard to efforts to preserve Balinese language and literature, it is necessary to have more serious and deeper studies to improve the positive attitude of Balinese people towards their cultural roots. The strategic role of Balinese language and its existence as a language that has a specific and unique speaking system is the background to the importance of this study.

Based on the understanding of the importance of the role and the function of the Balinese language, the purpose of this paper is to describe the identification of anggah-ungguh kruna basa Bali. (Balinese world level) which is a means or raw material in Balinese language is good and true. This study is a qualitative study discuss with structuralism theory. The source of data from a number of literature obtained by research literature and field research with the observation method and interview, assisted by recording techniques. Data of research result obtained by analized descriptive method.

\section{Research Methods}

The existence of the Balinese language is stratified at first referred to by a number of terms such as sor singgih basa Bali (Tinggen, 1982) undag-undagan basa Bali, and Warna-warna Basa Bali. Since 1974 after the Pasamuhan Agung Bahasa Bali in Singaraja, the term of the Balinese language levels is referred to as anggahungguhing basa Bali.

Prior to that, in 1957, 1970, 1984, the Dutch writer named J. Kersten, S.V.D. calling sor -singgih basa Bali with the term Warna-warna Basa Bali. Udayana University Faculty of Literature Team 1988/1989 called it Unda Usuk Basa Bali, Nengah Tinggen (1984) until now still call it as Sor Singgih Basa Bali. However, the term was popularized back in 1983 by Ida Bagus Air Naryana in his thesis entitled "Anggah-ungguhing Basa Bali" in the Association of Balinese Society".

Anggah-ungguhing basa in Balinese language that has been inherited since the first and still exist until now originated from the differences in social status of the people of Bali. Balinese and traditional Balinese coatings are the main cause of the Balinese language of terraced stages (anggah -ungguhing basa Bali). When viewed from the Balinese community of tradition, Balinese society consists of four levels of descendants called catur kasta or catur wangsa, including: brahmana, ksatria, waisia, and sudra (common people).

Then after having their respective professions, came the modern Balinese society which consisted of the upper and lower classes (Kersten, 1974). The upper classes are those who have important positions or elites which in this paper are called prakangge / prayayi and lower classes are people whose social status and / or profession are inferior and in this paper is called prajana (ordinary people).

This Balinese society coating is derived from birth/heredity. Some are born in geria (ida peranda, ida ayu, ida bagus), in puri (ida cokorda, ida anaké agung), born in jeroan (dané gusti ayu, dané gusti agung, dané désak, déwa, ngakan, siluh, mekel). There is also a group of lower classes born in pacanggahan, umah (house). Such as: i putu, $i$ wayan, i madé, ni kadék, i nyoman, ni komang, ni ketut, and so on.

Suwija, I. N. (2017). Identification of Anggah-ungguh Kruna Balinese language. International Journal of Linguistics, Literature and Culture, 3(6), 14-21. https://doi.org/10.21744/ijllc.v3n6.2 
The existence of two groups of descendants that gave birth to the upper class society (tri wangsa) and lower class (wangsa jaba).

1) Tri Wangsa, the three offspring called the upper class or sang singgih, the descendants of Brahmana (born in geria), Ksatria (born in puri), and Wésia (born in jero).

2) Wangsa Jaba, the lower class (sang sor) is a Balinese society derived from the descendants of Sudra Wangsa (those born at home).

Furthermore, in layers of modern Balinese society, after society has its own function or profession, it is distinguished by elite/officials (prakanggé or prayayi) and ordinary people or prajana.

1) Prakanggé/Prayayi, the upper class called sang singgih, the Balinese people who are trusted in the community as officials, such as: official officials (employers, directors, managers, rector, deans, lectures, regent, head of district, head of department, and others) and traditional officials (sulinggih, bendésa, jero gede, pemangku, panyarikan, patengen, kelian, etc.).

2) Parajana, the modern Balinese society called lower class (sang sor), that is the Balinese people who have low-ranking functions or professions, serving or working as officials of officials, such as sweepers, drivers, mail typewriters, clerks, students, students, laborers, maids, and others.

Based on the differences in social status mentioned above, there is a speech code which is the norm or standard rule in Balinese language as follows.

1) Wangsa Jaba, when speaking or talking about the Tri Wangsa, is obliged to use the subtle Balinese language (basa alus).

2) Tri Wangsa, when speaking or about Wangsa Jaba, may speak andap (off-respect) or speak madia (medium).

3) Parajana (officers or persons of lower social standing), when speaking to a superior official (prakanggé or prayayi) should speak alus.

4) Prakanggé or prayayi, when speaking to parajana (lower class), it is true to speak andap (out of respect) or madia (medium).

\section{Results and Analysis}

\section{Anggah-ungguh Kruna Basa Bali}

Anggah-ungguh kruna is used to refer to the vocabulary level in Balinese speech acts based on differences in social status of the talking parties. So the existence of different layers of Balinese society is in terms of birth and role in life in society, Balinese words have different taste values as well. According to the value of taste, Balinese words are distinguished on: (1) Kruna nenten alus, is ordinary or respectful words, including: kruna andap, kruna mider, and kruna kasar, (2) Kruna Alus, words which has a fine or respectable taste value, includes: kruna alus mider, alus madia, alus singgih, and kruna alus sor.

\subsection{Kruna Nenten Alus}

Known Balinese languages include a specific and unique language that has a high-level speech system or is known to have anggah-ungguhing basa Bali. This form is made up of words of varying taste value called masorsinggih. Balinese words that include kruna nenten alus are all words that include ordinary words that do not have a sense of respect value. (Naryana, 1983) refer to these words as honorable words, including crude words or kruna kasar, kruna mider, and kruna andap.

\section{1) Kruna Kasar}

Kruna kasar are Balinese words that feel bad (kaon). Rough words are used to form rough communication. That is why harsh words are commonly spoken in times of anger, when arguing or berating. In communicating, rough words as the main element in forming a coarse sentence, as a basis also in forming basa kasar.

Examples kruna kasar, bold and tilted kruna below.

a) Madak ba pang bangka polonné.

b) Nyén kadén ngamah béné?

c) Cicing Ih, delikang matan ibané! 
d) Nyén kadén nidik buah gedangé kanti has?

e) Lamun suba won atine, pedemang awaké ditu!

The words like (bangka polonne, ngamah, peta, cicing, delikang, nidik, pedemang) above, all examples of kruna kasar. The other examples of kruna kasar: bangka 'dead', amah /tidik/pantet 'feed', ake 'me', iba 'you', pules/medem 'sleep', tolih/not 'see, bungut 'mouth ', jlema 'someone ', and others.

\section{2) Kruna Mider}

The sense of kruna mider when compared with kruna alus mider (Ami) often leads to confusing thoughts. That causes it, because both kruna mider and kruna alus mider, can be used to respect (nyinggihang), can also be used degrading (ngasorang) the difference, kruna alus mider has a form andap, while kruna mider has no other form.

Thus, kruna mider are Balinese words that have only one form, do not have the form of alus singgih, alus sor, or alus mider, and do not have any other form, so it can use anywhere (maideran) in conversation. Consider the example below!

1) Ida kaun ka toko numbas karpét.

2) Ratu, nénten purun titiang, asu druéné galak pisan.

3) Mangkin sampun arang anak mirengang radio.

4) Titiang kénkéna nunas arit druén Ida Aji Ngurahé.

The words in italics and bold in the sentences above are kosata which includes kruna mider, namely: toko 'shop', karpet 'carpet', galak 'fierce', radio 'radio', kija 'where', and arit 'sickle. Other examples: nyongkok 'squats',' spidol 'markers, sendeh tilt', sepatu shoes', laptop 'laptop, tembok' wall ', and others.

Examples of sentences containing other kruna mider:

1) Ida Ayu, sampunang drika nyongkok, tunguné akéh drika.

2) Gusti Ngurah, sayuakti Gusti madué buku pupulan pidarta?

3) Sami ruangan kuliahé ring kampus sampun madaging $\mathbf{L C D}$.

4) Ratu jagi lunga kija makta koper ageng pisan? Ten baat?

\section{3) Kruna Andap}

In the beginning, kruna andap was called word out respect or kruna kapara. Kruna andap are words that are of ordinary value, out of respect or andap (low), not smooth and not rough. It is these words that form the sentences andap. It is used to speak by people of the same caste or status or birth. In addition, the words of andap after forming a sentence, can be used to speak by sang singgih (honorable class) to sang sor (group of honor).

The form of words belonging to kruna andap is similar to kruna mider. The difference, if kruna mider has no smooth form, but kruna andap must have a smooth shape. For example word "kija" (mider) there is no subtle form. In contrast to word "kaja" (andap), it has a smooth form of kaler.

The word kija can be used in language andap, can also be used in alus singgih, can be used in the language alus sor, can also be used in harsh language. For example:

1) Ratu jagi lunga kija?

2) Bapak lakar kija?

3) Ia kija kadén Luh Rai tusang maorahan?

In contrast to the word kaja (andap), because it has a subtle form of kalér. The word andap Kaja is only used to speak andap or rough, while the word kalér (Ami) should only be used in alus. For example:

1) Simané dini malénan ajak jumah kaja.

2) Sapunapi mangkin simakramané kaler, Ratu?

3) Bapak teka uli kaja busan dini.

Examples of other Kruna Andap: jemak 'grab', duur 'top', milu 'follow', kema' go there ', lakar will ', ngae' make ', adan' name ', and so on as in the example below.

1) Luh, jemakang bapa rokoné di duur mejané!

2) Kéngkén, cai lakar milu kema?

3) Nyén ja adané artisé ané ngaé vidio porno ento?

4) Apa kejangkrik ngecik duur gunungé?

Suwija, I. N. (2017). Identification of Anggah-ungguh Kruna Balinese language. International Journal of Linguistics, Literature and Culture, 3(6), 14-21. https://doi.org/10.21744/ijllc.v3n6.2 


\subsection{Kruna Alus}

As a result of the unique Balinese language speaking system, having a multilevel language or sor-singgih basa, in addition to the subtle words (nenten alus) above, there are quite a few Balinese words that include kruna alus, ie words that have a sense of respect, both for oneself for the speaker and for respect for others belonging to the upper classes (according to Kersten, 1974) or sang singgih (according to Suwija, 2014). Kruna alus include: (1) kruna alus singgih, (2) kruna alus sor, (3) kruna alus mider, and (4) kruna alus madia.

1) Kruna Alus Singgih (Asi)

The subtle words used to honor the respectable person are called kruna alus singgih. The difference with kruna Ami, that Kruna Asi must have a form andap, also has the form of alus sor (Aso). For example kruna Asi marayunan (eat), have wangun Andap madaar (eat), also have the form of alus sor ngajeng or nunas (eat). Words that are bold or italic, below are all examples of kruna alus singgih.

1) Rabinidané sampun mobot mangkin.

2) Okandané sané istri maparab Gusti Ayu Klatir.

3) Praragan Ratu rauh meriki?

4) Bapak wénten nyingakin bapan titiangé?

Words such as: mobot 'pregnant' in sentence (1), maparab 'named' in sentence (2), praragan 'alone' in sentence (3), nyingakin 'see' in sentence (4), and mantuk go home' in sentence (5), is an example of kruna alus singgih. Other examples: seda 'died', ida dane 'ladies and gentlemen', mobot, 'pregnant', manggihin 'meet', mapesengan 'named', mireng 'hear', and others. Examples of other Asi sentences:

1) Tedun Ida Anaké Agung, raris Ida makoratan.

2) Sampun kudang diri okan Gustiné madué oka?

3) Ida Peranda sampun lebar kocap ring rumah sakit.

4) I Gusti Ngurah Rai lina ring perang Puputan Margarana.

5) Ampura Ratu, Ratu wenten manggihin bapak titiange?

\section{2) Kruna Alus Sor (Aso)}

Kruna alus sor is a Balinese word that has a sense of fine or honorable value, is used to humble oneself or demean other people with lower social status. Thus, who will speak alus sor in social, all the Balinese people who regard themselves as having lower status in speech. Bold under, for example kruna alus sor.

1) Jantos jebos titiang jagi mabanyu riin!

2) Banggayang Ratu, titiang jagi néwék tangkil ka geria!

3) Titiang mawasta I Wayan Mudara.

4) Ipun sampun dumunan padem.

So, based on the example of the above, which includes kruna alus sor, among others: mabanyu 'pee', newek 'own', tangkil 'facing', mawasta 'named', neda 'eat', padem 'died'. Other examples: manah 'mind', sengkaon 'sick', antuk 'by', matur 'talk', muat 'bring', and others. Example of another sentence:

1) Titiang nénten miragi orti, Ratu wénten mireng?

2) Buku punika kasurat antuk Pak Nyoman Suwija.

3) Inggih, sampun titiang sané ngaturang jinahé ka puri.

4) Ida dané, sadurung nglanturang matur, lugrayang titiang nyinahang déwék!

\section{3) Kruna Alus Mider (Ami)}

Kruna alus mider is a Balinese word that has a fine taste value, and has two functions, can be used to salute (nyinggihang the singgih) and also used to lower the lower class (ngesorang the sor). In addition, kruna alus mider must have the usual form (andap) (Suasta, 1997: 26). The words that written and bold words below, for example kruna alus mider (Ami).

1) Ida Cokorda sampun rauh saking Jawi. (Asi)

2) Bapak titiang sampun rauh saking Jawi. (Aso)

In the sentences (1) and (2) above, there are definitely four words / kruna that have a sense of alus mider: word sampun, rauh, saking, and Jawi. 
What causes these four words is called kruna alus mider because it is used in the sentence Asi (as in sentence no.1), can also be used in the sentence Aso (as in No. 2). In addition, the four words of Ami have form andap. The word rauh andap teka; word sampun andap suba, saking andap uli; and Jawi andap Jawa. That caused these four words include the word or kruna alus mider. Another example of kruna alus mider: uning 'know', lali 'forget', eling "remember", sampun 'already', ngambil 'take'

Example kruna alus mider (Ami) shaped sentence:

1) Ampura ping banget, titiang nénten uning. Ratu uning?

2) Ratu pasti lali ring titiang nggih? Titiang nénten naenan lali.

3) Titiang kantun éling ring Ratu. Rabin Iratuné éling taler ring titiang.

4) Ratu, icén ja titiang nyelang HP druené! Ratu durus jagi nyelang jinah?

\section{4) Kruna Alus Madia (Ama)}

Kruna alus madia (Ama) are words whose language between alus singgih (Asi) and alus sor (Aso). Kruna alus madia appears to be a variation of other Kruna alus (Bagus, 1979: 179). In addition, there are indeed Balinese words that taste the language alus madia, alus menengah, or less good if used subtle language. Consider the example of the sentence below!

1) Tiang nika ngelah.

2) Nggih tiang ampun nunas I wawu.

3) Ipun ten wénten drika.

4) Niki sira nuénang?

All these bolded words (tiang, nika, nggih, ampun, ten, drika, niki, nika) are examples of kruna alus madia. If the words below are used to communicate, the communication will use basa madia. Another example of kruna alus madia: niki 'this', nika 'that', ampun 'already', tiang 'I', nggih 'alright'.

Example kruna alus madia in the sentence:

1) Ampunang nika ambila, niki wawu dados ambil!

2) Nika druén Atuné, niki tiang ngelah.

3) Atu ampun polih ka Art Center? Tiang during merika.

4) Nggih atu, malih jebosan tiang jagi merika.

\section{Conclusion}

Based on the explanation above, it can be concluded that the Balinese language has a specific and unique talk system known as anggah-ungguh basa Bali. As a result of the existence of traditional layers of society (kasta) and the layers of modern society based on social status in certain positions, the Balinese language vocabulary consists of seven types of word levels called anggah ungguh kruna basa Bali. The seven types of vocabulary levels are (1) kruna kasar, (2) kruna mider, (3) kruna andap, (4) kruna alus singgih, (5) kruna alus sor, (6) kruna alus mider, and (7) kruna alus madia.

The following conclusions can be suggested that efforts to carry out various academic and practical activities that lead to the preservation of Balinese script, language and literature should continue to be improved even in quality and quantity.

\section{Acknowledgments}

My deep and sincere gratitude were presented to God for having granted me the ability and the opportunity to complete this paper. I would also like to thank my former lecturers and my friend for their support, their patience, their contribution, and their valuable input, therefore, this article could be completed. I would also thank I Wayan Suryasa as an advisor as well as editor in chief of IJMRA and SKIREC who has reviewed and approved this study to be published. In order to readers, it is better the research related Balinese literature should be deepened and developed for preserving and the preservation of language and literature not in danger for Balinese culture.

Suwija, I. N. (2017). Identification of Anggah-ungguh Kruna Balinese language. International Journal of Linguistics, Literature and Culture, 3(6), 14-21. https://doi.org/10.21744/ijllc.v3n6.2 


\section{References}

Arka, I. W. (2013). Language management and minority language maintenance in (eastern) Indonesia: strategic issues.

Crime, M. (2017). CULTURE, MASCULINITIES AND VIOLENCE AGAINST WOMEN. Crime, Criminal Justice and Masculinities.

Naryana, U. I. B. (1983). Anggah-ungguhing basa Bali dan peranannya sebagai alat komunikasi bagi masyarakat suku Bali. Denpasar: Fakultas Sastra Unud.

Suarjana, P. I. N. (2011). Sor Singgih Bahasa Bali (ke-bali-an Manusia Bali Dalam Dharma Peparikan, Pidarta, Sambrama Wecana dan Dharma Wecana).

Suasta, I. M. (1997). Berpidato dengan bahasa Bali. Jurusan Sastra Daerah, Fakultas Sastra, Universitas Udayana.

Suwija, I. N. (2014). Tata titi mabaos Bali. Pelawa Sari.

Tinggen, I. N. (1995). Sor singgih basa Bali: istilah Indonesia-Bali. Rhika Dewata. 


\section{Biography of Author}

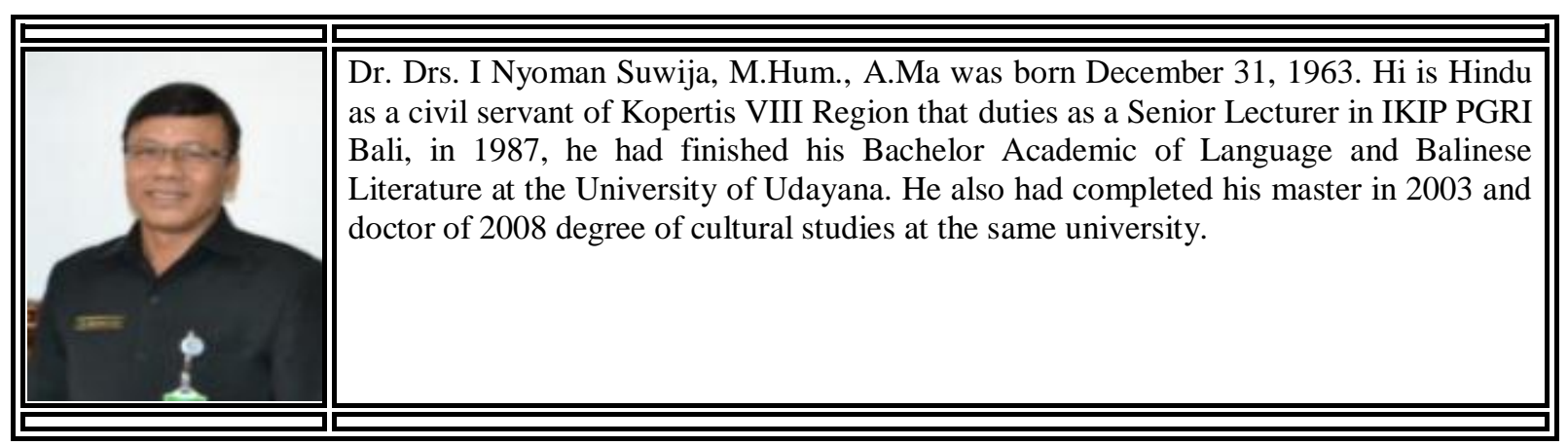

Suwija, I. N. (2017). Identification of Anggah-ungguh Kruna Balinese language. International Journal of Linguistics, Literature and Culture, 3(6), 14-21. https://doi.org/10.21744/ijllc.v3n6.2 